\title{
PENGARUH PEMBELAJARAN KOOPERATIF TIPE GROUP INVESTIGATION (GI) TERHADAP KEMAMPUAN PENALARAN MATEMATIS SISWA MTs
}

\author{
Nego Linuhung ${ }^{1)}$, Satrio Wicaksono Sudarman ${ }^{2)}$ \\ Pendidikan Matematika FKIP Universitas Muhammadiyah Metro \\ E-mail: nego_mtk@yahoo.co.id ${ }^{1)}$,rio_sudarman@yahoo.com ${ }^{2)}$
}

\begin{abstract}
The research was conducted to find out the influence of Group Investigation (GI) of Cooperative Learning methods toward the student's ability of mathematical reasoning. The research design was quasi-experimental the nonequivalent posttest-only control group design consisting of one experimental class (Group Investigation of Cooperative Learning) and one control class. The research population was all the second-semester students of VIII grade of MTs Negeri 1 Lampung Timur in the academic year of 2015/2016. The research instruments used were mathematical reasoning ability test. Data Analyze mathematical reasoning ability was used independent sample t-test. The results showed that: (1) mathematical reasoning ability using Group Investigation of Cooperative Learning was higher than conventional learning.
\end{abstract}

Keywords: Mathematical Reasoning Ability, Group Investigation (GI) of Cooperative Learning.

\section{PENDAHULUAN}

Mata pelajaran matematika diberikan kepada semua peserta didik mulai dari sekolah dasar untuk membekali peserta didik dengan kemampuan berpikir logis, analitis, sistematis, kritis, dan kreatif, serta kemampuan bekerjasama. Pembelajaran matematika yang diberikan di sekolah harus dapat mengasah siswa agar mereka memiliki kompetensi dasar dalam matematika sesuai dengan tujuan umum pembelajaran matematika.
Tujuan pembelajaran matematika lebih rinci dijelaskan dalam Kurikulum Tingkat Satuan Pendidikan (Depdiknas, 2006: 345) yaitu:

1. memahami konsep matematika, menjelaskan keterkaitan antar konsep dan mengaplikasikan konsep atau algoritma, secara luwes, akurat, efisien, dan tepat, dalam pemecahan masalah;

2. menggunakan penalaran pada pola dan sifat, 


melakukan manipulasi
matematika
membuat dalam
menyusun beneralisasi,
menjelaskan gagasan dan
pernyataan matematika;

3. memecahkan masalah yang meliputi kemampuan memahami masalah, merancang model matematika, menyelesaikan model dan menafsirkan solusi yang diperoleh;

4. mengkomunikasikan gagasan dengan simbol, tabel, diagram, atau media lain untuk memperjelas keadaan atau masalah;

5. memiliki sikap menghargai kegunaan matematika dalam kehidupan, yaitu memiliki rasa ingin tahu, perhatian,

6. dan minat dalam mempelajari matematika, serta sikap ulet dan percaya diri dalam pemecahan masalah.

Berdasarkan tujuan pembelajaran matematika yang kedua, menunjukkan bahwa kemampuan penalaran matematis merupakan kemampuan yang harus dikuasai peserta didik SMP/MTs dalam membuat generalisasi, menyusun bukti, atau menjelaskan gagasan dan pernyataan matematika. Kemampuan penalaran dalam pembelajaran matematika perlu dikembangkan, karena dapat membantu siswa meningkatkan kemampuan dalam matematika, yaitu dari yang hanya sekedar mengingat kepada kemampuan pemahaman.

Kenyataan di lapangan belum sesuai dengan yang diharapkan. Pada umumnya guru masih mengajarkan konsep matematika secara searah dan berpusat pada guru, sehingga siswa merasa malas untuk mempelajari matematika karena siswa menganggap bahwa pelajaran matematika adalah pelajaran yang membosankan. Siswa juga masih merasa bingung dalam mengaplikasikan konsep matematika dalam kehidupan sehari-hari karena soal yang diberikan adalah soal-soal rutin yang kurang meningkatkan kemampuan penalaran matematis, sehingga siswa tidak terlatih untuk menyelidiki dan menyelesaikan masalah yang diberikan oleh guru. Selanjutnya.

Riyanto (2011:113) mengemukakan salah satu penyebab kurangnya kemampuan penalaran dan prestasi matematika siswa adalah proses pembelajaran yang dilakukan oleh guru di kelas kurang melibatkan siswa dalam proses pembelajaran atau tidak terjadi diskusi antara siswa dengan siswa dan siswa dengan guru.

Dalam proses pembelajaran, siswa tidak mengeksplorasi, menemukan sifat-sifat, menyusun konjektur kemudian mengujinya tetapi hanya menerima apa yang 
diberikan oleh guru atau siswa hanya menerima apa yang dikatakan oleh guru. Kemampuan penalaran matematis dirasa masih lemah, berdasarkan hasil wawancara dan observasi yang dilakukan terkait pembelajaran matematika di sekolah tempat penelitian dilakukan, ditemukan beberapa masalah diantaranya adalah siswa mengalami kesulitan mengungkapkan ide matematis baik secara lisan, tulisan maupun model matematika.

Pada penelitian ini peneliti berusaha mengetahui bagaimana esensi dari pembelajaran terhadap kemampuan penalaran matematis. Model pembelajaran kooperatif ini menekankan pada partisipasi dan aktivitas siswa untuk mencari sendiri materi (informasi) pelajaran yang akan dipelajari melalui bahan-bahan yang disediakan.

Pembelajaran kooperatif tipe GI dalam Suprijono (2013) dimulai dengan pembagian kelompok, selanjutnya guru bersama perserta didik melihat topik-topik tertentu dengan permasalahan-permasalahan yang dapat dikembangkan dari topiktopik itu. Sesudah topik beserta permasalahannya disepakati, peserta didik beserta guru menentukan metode penelitian yang dikembangkan untuk memecahkan masalah. Setiap kelompok bekerja berdasarkan metode investigasi yang telah mereka rumuskan. Aktivitas tersebut merupakan kegiatan sistemik keilmuan mulai dari mengumpulkan data, analisis data, sintesis, hingga menarik kesimpulan. Langkah berikutnya adalah presentasi hasil oleh masing-masing kelompok dan di akhir pembelajaran dilakukan evaluasi. Evaluasi dapat memasukkan assesmen individual atau kelompok.

Pada penelitian ini tahaptahap pembelajaran kooperatif tipe GI dapat diaplikasikan dalam skala kondisi kelas yang luas yang dikemukakan oleh (Slavin, 2009: 218) yaitu: Tahap 1, Mengidentifikasikan topik dan mengatur murid ke dalam kelompok; Tahap 2: Merencanakan tugas yang akan dipelajari; Tahap 3: Melaksanakan Investigasi; Tahap 4: Menyiapkan laporan akhir. Tahap 5: Mempresentasikan laporan akhir Tahap 6: Evaluasi

Berdasarkan langkah-langkah dan tujuan pembelajaran kooperatif tipe GI diduga dapat meningkatkan penalaran matematis siswa Mts Negeri di Lampung Timur. Secara umum rumusan masalah penelitian ini adalah "Apakah Kemampuan penalaran matematis siswa yang memperoleh Pembelajaran Kooperatif Tipe GI lebih tinggi daripada siswa yang memperoleh pembelajaran konvensional?" 


\section{METODE PENELITIAN}

Penelitian yang akan dilakukan adalah penelitian quasi eksperimen karena peneliti menerima subjek penelitian apa adanya, artinya subjek penelitian tidak dikelompokkan secara acak, sehingga dapat diterapkan dengan mudah dalam dunia pendidikan. desain penelitian berbentuk "the noneequivalent posttest-only control group design".

Penelitian ini dilaksanakan di MTs Negeri 1 Lampung Timur Tahun Pelajaran 2015/2016. Populasi dalam penelitian ini adalah siswa-siswa MTs Negeri 1 Lampung Timur Tahun Pelajaran 2015/2016. Sampel penelitian diambil dari siswa kelas VIII, yaitu 2 kelas Kelas eksperimen adalah kelas yang mendapat pembelajaran kooperatif tipe GI dan kelas kontrol adalah kelas yang mendapat pembelajaran konvensional.

Penelitian ini menggunakan cara pengumpulan data yaitu teknik tes. Teknik tes bertujuan untuk mengetahui kemampuan penalaran siswa, yaitu meliputi posttest. Kemudian data yang telah terkumpul dilakukan perhitungan secara statistik rata-rata kemampuan penalaran matematis siswa. Pengolahan data kuantitatif dilakukan dengan menggunakan uji statistik terhadap skor posttest Untuk menentukan uji statistik yang akan digunakan, terlebih dahulu diuji normalitas data dan homogenitas varians. Sebelum uji tersebut dilakukan harus ditentukan terlebih dahulu rata-rata skor serta simpangan baku untuk setiap kelompok. Untuk lebih jelasnya, setelah diperoleh data posttest selanjutnya diolah melalui tahap tahap sebagai berikut:

1. Memberikan skor jawaban siswa sesuai dengan kriteria penskoran yang digunakan

2. Analisis data diawali dengan melakukan uji normalitas, uji homogenitas varians dan uji perbedaan dua rata-rata.

\section{HASIL PENELITIAN DAN PEMBAHASAN}

Pengolahan data hasil penelitian ini bertujuan untuk membandingkan pencapaian kemampuan penalaran matematis siswa yang mendapatkan pembelajaran Kooperatif tipe GI dengan siswa yang memperoleh pembelajaran secara konvensional. Untuk mengukur kemampuan penalaran matematis siswa, digunakan tes berbentuk uraian, yang diberikan kepada siswa sebagai posttest. Data skor hasil dari posttest kelas eksperimen dan kelas kontrol dianalisis untuk melihat perbedaan kemampuan kedua kelas

\section{Kemampuan Penalaran Matematis}

Data kemampuan penalaran matematis diperoleh dari hasil posttest kelas eksperimen dan kelas kontrol. 
Tabel 1. Statistik Deskriptif Kemampuan Penalaran Matematis

\begin{tabular}{|c|r|r|r|r|r|}
\hline \multirow{2}{*}{ Nilai } & \multicolumn{5}{|c|}{ Posttest } \\
\cline { 2 - 6 } & $\mathbf{N}$ & \multicolumn{1}{|c|}{$\mathbf{X}_{\text {min }}$} & \multicolumn{1}{c|}{$\mathbf{X}_{\text {maks }}$} & \multicolumn{1}{c|}{$\bar{c}$} & \multicolumn{1}{c|}{ SD } \\
\hline Eksperimen & 36 & 54 & 88 & 71,47 & 9,15 \\
\hline Kontrol & 36 & 50 & 85 & 66,67 & 9,66 \\
\hline
\end{tabular}

Berdasarkan Tabel 1. Skor minimum dan maksimum skor posttest untuk kelas yang memperoleh pembelajaran Kooperatif tipe GI adalah 54 dan 88 dengan Standar Deviasi 9,15 , sedangkan skor minimum dan maksimum skor posttest untuk kelas yang memperoleh pembelajaran konvensional adalah 50 dan 85 dengan Standar Deviasi 9,66. Selanutnya, rataan skor posttest kemampuan penalaran matematis untuk kelas eksperimen sebesar 71,47 dan kelas kontrol sebesar 66,67. Berikut secara ringkas disajikan perbandingan rataan skor posttest kemampuan penalaran matematis siswa kelas Eksperimen dan kontrol.

Untuk lebih jelasnya dapat dibuat diagram perbandingan rataan posttest sebagai berikut:

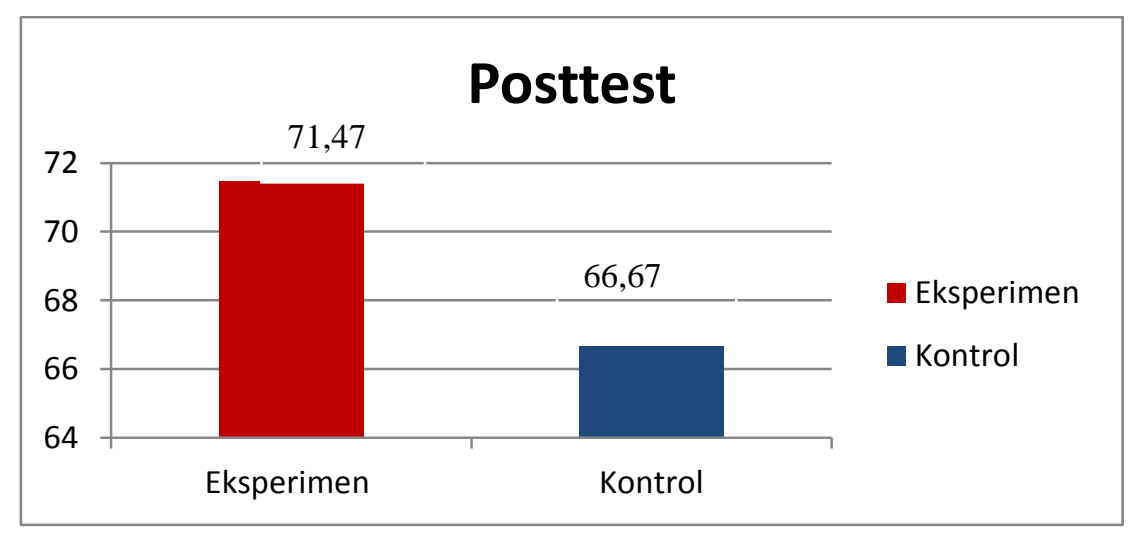

Gambar 1. Perbandingan Rataan Posttest Penalaran Matematis Siswa

2. Analisis

Penalaran Matematis Setelah Pembelajaran

Analisis kemampuan penalaran matematis setelah pembelajaran menggunakan uji perbedaan rataan posttest untuk melihat perbedaan kemampuan akhir setelah diberikan dua perlakuan yang berbeda. Untuk itu, terlebih dahulu dilakukan uji prasyarat yaitu: uji normalitas dan uji homogenitas. Berdasarkan hasil uji normalitas diperoleh skor posttest kelas ekperimen 0,130 dan kontrol 2,00. Keduanya memiliki nilai Sig. 
$>\alpha$, sehingga dapat disimpulkan bahwa kemampuan penalaran matematis kelas eksperimen dan kontrol berdistribusi normal.

Selanjutnya, karena kedua sampel berasal dari populasi yang berdistribusi normal, maka dilakukan uji homogenitas. Uji homogenitas bertujuan untuk mengetahui apakah kedua sampel berasal dari populasi yang variansinya sama atau tidak. Uji homogenitas dilakukan dengan menggunakan uji Homogenity of Variances (Levene Statistic).

Berdasarkan hasil pengujian homogenitas memperlihatkan bahwa skor posttest memiliki Sig. lebih besar dari $\alpha=0,05$ yaitu 0,973 , sehingga $\mathrm{H}_{0}$ diterima. Hal ini berarti, skor posttest kemampuan penalaran matematis siswa kelas eksperimen dan kelas kontrol berasal dari varians yang sama. Selanjutnya, dapat dilakukan uji perbedaan dua rataan posttest dengan menggunakan uji- $t$ atau independent sample t-test, pada taraf signifikansi $\alpha=0,05$.

Uji perbedaan bertujuan untuk mengetahui perbedaan rataan posttest. Berdasarkan hasil uji normalitas dan homogenitas skor posttest kelas eksperimen dan kelas kontrol, bahwa data kedua kelas berdistribusi normal dan varians kedua kelas homogen, maka bisa dilanjutkan pada uji perbedaan posttest menggunakan independent sample t-test. Berikut adalah rangkuman hasil uji perbedaan rataan posttest kemampuan penalaran matematis dapat dilihat pada Tabel 2

Tabel 2. Uji Perbedaan Rataan Skor Kemampuan Penalaran Matematis Setelah Pembelajaran

\begin{tabular}{|l|l|l|l|l|}
\hline \multicolumn{4}{|c|}{ t-test for Equality of Means } & \multirow{2}{*}{ Keterangan } \\
\cline { 1 - 4 } $\mathbf{t}$ & $\boldsymbol{f}$ & $\begin{array}{l}\text { Sig. (2- } \\
\text { tailed) }\end{array}$ & $\begin{array}{l}\text { Sig. (1- } \\
\text { tailed) }\end{array}$ & \\
\hline, 168 & 0 & 0,034 & 0,017 & $\mathrm{H}_{0}$ Ditolak \\
\hline
\end{tabular}

Hasil uji perbedaan rataan posttest kelas eksperimen dan kelas kontrol tersebut diketahui bahwa nilai Sig. (1-tailed) yaitu 0,017 lebih kecil dari nilai $\alpha=$ 0,05 , sehingga $\mathrm{H}_{0}$ ditolak. Hasil ini berarti kedua kelas memiliki kemampuan penalaran matematis yang berbeda secara signifikan, sehingga dapat disimpulkan bahwa kemampuan penalaran matematis siswa yang memperoleh Pembelajaran Kooperatif tipe GI lebih tinggi daripada siswa yang memperoleh pembelajaran konvensional

Secara umum pelaksanaan pembelajaran Kooperatif tipe GI berjalan sesuai dengan yang diharapkan. Pembelajaran 
kooperatif tipe GI merupakan salah satu model pembelajaran kooperatif yang menekankan pada partisipasi dan aktivitas siswa untuk mencari sendiri materi (informasi) pelajaran yang akan dipelajari melalui bahan-bahan yang tersedia. Siswa dilibatkan sejak perencanaan, baik dalam menentukan topik maupun cara untuk mempelajarinya melalui investigasi. Berdasarkan analisis data yang telah diuraikan dapat disimpulkan bahwa pembelajaran Kooperatif tipe GI berpengaruh terhadap pencapaian kemampuan penalaran matematis matematis siswa.

Hal ini tentunya sesuai dengan yang dijelaskan sebelumnya bahwa pembelajaran kooperatif tipe GI merupakan salah satu model pembelajaran kooperatif yang menekankan pada partisipasi dan aktivitas siswa untuk mencari sendiri materi (informasi) pelajaran yang akan dipelajari melalui bahan-bahan yang tersedia dan dapat melatih siswa untuk menumbuhkan kemampuan berfikir mandiri, keterlibatan siswa secara aktif dapat terlihat mulai dari tahap awal sampai dengan tahap akhir sehingga menyebabkan kemampuan penalaran matematis kelas eksperimen lebih tinggi daripada kelas kontrol.

Hasil uji skor posttest menggunakan independent sample t-test menghasilkan kesimpulan bahwa kemampuan penalaran matematis siswa yang belajar dengan pembelajaran GI lebih tinggi secara signifikan dibandingkan dengan siswa yang belajar dengan pembelajaran Konvensional. Hasil penelitian ini sesuai dengan penelitian-penelitian yang telah dilakukan sebelumnya yaitu penelitian tesis yang dilakukan oleh Solekha, dkk. (2013) diperoleh kesimpulan bahwa kemampuan komunikasi matematis siswa dengan model Group Investigation lebih tinggi dibandingkan pembelajaran konvensional. Fitriana (2010) menyimpulkan bahwa prestasi belajar matematika siswa dengan model pembelajaran cooperative tipe GI lebih baik dari pada model pembelajaran cooperative tipe STAD dan prestasi belajar matematika siswa yang mempunyai kemandirian belajar tinggi lebih baik daripada prestasi belajar matematika siswa yang mempunyai kemandirian belajar sedang maupun rendah. Ditasona (2013) menunjukkan perbedaan peningkatan kemampuan penalaran matematis siswa antara siswa yang memperoleh pembelajaran Differentiated Instruction. Selanjutnya penelitian yang dilakukan oleh Riyanto (2011). Diperoleh kesimpulan bahwa: Terdapat pengaruh kemampuan penalaran terhadap prestasi siswa, yaitu prestasi siswa yang kemampuan penalarannya tinggi lebih baik daripada siswa yang penalarannya rendah. 
Pembelajaran kooperatif tipe GI melatih siswa untuk berpikir tingkat tinggi, menumbuhkan kemampuan berfikir mandiri, keterlibatan siswa secara aktif pada proses pembelajaran penyelidikan terhadap masalah yang diberikan oleh guru membuat siswa terlatih untuk menyelesaikan masalah dan juga merasa menikmati proses pembelajaran yang dilaksanakan di kelas. Hal tersebut merupakan faktor yang mempengaruhi kemampuan penalaran matematis siswa yang belajar dengan pembelajaran GI berbeda secara signifikan dengan peningkatan kemampuan penalaran matematis siswa yang belajar dengan pembelajaran Konvensional.

\section{KESIMPULAN DAN SARAN}

Berdasarkan hasil analisis data dan pembahasan mengenai pengaruh model pembelajaran Kooperatif Tipe GI terhadap kemampuan penalaran matematis siswa M.Ts berikut merupakan kesimpulan mengenai perbedaan kemampuan penalaran matematis antara siswa yang mendapatkan pembelajaran koopertif tipe GI dan siswa yang mendapatkan pembelajaran Konvensional bahwa: "Kemampuan penalaran matematis siswa yang memperoleh pembelajaran Kooperatif Tipe GI lebih tinggi daripada siswa yang memperoleh pembelajaran konvensional".
Berdasarkan kesimpulan di atas, maka penulis mengemukakan beberapa saran sebagai berikut:

1. Hasil penelitian ini menunjukkan bahwa model pembelajaran Kooperatif Tipe GI dapat meningkatkan kemampuan penalaran matematis siswa dalam matematika. Sebaiknya pembelajaran dengan menggunakan model pembelajaran Kooperatif Tipe GI dapat digunakan sebagai upaya untuk meningkatkan kemampuan penalaran siswa.

2. Bagi peneliti selanjutnya agar mengkaji bagaimana pengaruhnya pada kemampuan matematis yang lain seperti pada kemampuan pemecahan masalah, representasi, komunikasi dan kemampuan matematis lainnya

\section{DAFTAR PUSTAKA}

Depdiknas. 2006. Kurikulum 2006 Mata pelajaran Matematika SMP/MTs. Jakarta. Departemen Pendidikan Nasional.

Ditasona, C. 2013. Penerapan Pendekatan Differentiated Instruction dalam Peningkatan Kemampuan Pemecahan Masalah dan Penalaran Matematis Siswa SMA. Bandung. UPI 
Fitriana, L. 2010. Pengaruh Model Pembelajaran

Cooperative Tipe Group Investigation (GI) dan STAD Terhadap Prestasi Belajar Matematika Ditinjau Dari Kemandirian Belajar Siswa. Tesis. Surakarta. Universitas Sebelas Maret

Riyanto, B. 2011. Meningkatkan Kemampuan Penalaran dan Prestasi Matematika Dengan Pendekatan Konstruktivisme Pada Siswa Sekolah Menengah Atas. Jurnal Pendidikan Matematika, Volume 5. NO. 2. 111-128. Diakses 15 april 2015.

Slavin. 2009. Cooperative Learning, Riset dan Praktek. Bandung: Nusa Media

Solekha, F. N., Noer, S. H. \& Gunowibowo, P. (2013). Pengaruh Model Pembelajaran Kooperatif Tipe Group Investigation terhadap kemampuan komunikasi matematis siswa. Jurnal Pendidikan Matematika Unila. Vol 1, No 9 (2013).

Suprijono, A. 2013. Cooperative Learning (teori \& aplikasi paikem. Yogyakarta: Pustaka pelajar. 